Comunicação. Miocardite chagásica aguda humana: provável agressão à célula cardiaca pelo granulócito eosinófilo. Tajuri WL. Lopes ER, Chapadeiro E, Miziara HL, Santos BG. Raso P. Revista da Sociedade Brasileira de Medicina Tropical 16:122-124, AbrJun, 1983

\section{REFERENCIAS BIBLIOGRĀFICAS}

1. Butterworth AE, David JR. Eosinophil function. The New England Journal of Medicine 15: 154-156, 1981.

2. Lopez AF, Moreno MMB, Sanderson CJ. The lysis of Trypanosoma cruzi epimastigotes by eosinophils and neutrophils. International Journal of Parasitology 8 : 485-489, 1978.

3. Ribeiro dos Santos R. Imunologia da destruição neuronal na doença de Chagas experimental. Tese de Livre Docência. Faculdade de Medicina de Ribeirăo Preto, 1977.

4. Ribeiro dos Santos R, Silva JS. Doença de Chagas. Resposta imune humoral e celular. Revista Goiana de Medicina 26: 115-123, 1980.

5. Santos-Buch CA, Teixeira ARL. The immunology of experimental Chagas disease. 111 - Rejection of allo- geneic heart cell in vitro. The Journal of Experimental Medicine 140: 38-53, 1974.

6. Tafuri WL, Chiari E, Raso P, Bogliolo L. Ciclo intracelular do $T$. cruzi e sua importância na patogênese da doença de chagas. In: Resumos da VIII Reunião Anual sobre Pesquisas Básicas em Doença de Chagas, Caxambu, p. 37, 1981.

7. Teixeira ARL, Santos-Buch CA. The immunology of experimental Chagas disease. II - Delayed hypersensitivity to Trypanosoma cruzi antigens. Immunology 28: 401-410, 1975.

8. Teixeira ARL, Teixeira ML, Santos-Buch CA. The immunology of Chagas disease. IV - Production of lesions in rabbits similar to those of chronic Chagas disease in man. American Journal os Pathology 80: $163-178,1975$.

\title{
TUMORAL FORM OF ASCARIASIS
}

\author{
Eduardo A. Bambirra, Ana Margarida M.F. Nogueira e Inez Andrade
}

Ectopic forms of ascariasis with tumoral mass formations in the abdominal cavity are extremely rare. We can trace only two cases in the medical literature $^{12}$. Recently we have seen one such case associated with a past history of traumatic enteroperitoneal fistulae (air pistol accident) in a 7 yearold male Brazilian child with concomitant intestinal ascariasis. Clinically a pre-operative diagnosis of abdominal cancer was made. During exploratory laparotomy a large, firm tumoral mass simulating a benign peritoneal neoplasm $(12 \times 5 \times 4 \mathrm{~cm})$ was found in the peritoneal cavity, loosely attached to the bowel, but without involvement of its wall. Excision was simple with no intestinal damage. Recovery was without complications. The histological preparation showed a marked fibrous reaction around preserved and/or degenerated as-

\footnotetext{
Departamento de Patologia da Faculdade de Medicina, Universidade Federal de Minas Geraís C.P. $340-30000$ Belo Horizonte, MG, Brasil.
}

caris eggs. Tissue eosinophilia was always present around the eggs which were frequently embryonated and contained 2,4 and 8 cell morulas. There were also areas of abscess formation and a granulomatous reaction with many foreign body giant cells. Serial sections of the excised mass did not revealed larvae and adult worms.

Although ascariasis is a very frequent infections in Brazil, this clinico-pathological form is very rare. We think that term tumoral form of ascariasis more adequate describes this peculiar clinicopathological presentation which simulates an abdominal neoplasm.

\section{REFERENCES}

1. Ramos CCF, Ramos AMD, Carvalho ARL. Pseudotumorous form of ascariasis. Report of a case. American Journal of Tropical Medicine and Hygiene 29: $795,1980$.

2. Wanick LR, Wanick MG. Pseudo fibroma da parede abdominal com reação local aos ovos de Ascaris lumbricoides em localização errática. Revista do Instituto de Antibióticos 11: 73, 1971. 